\title{
Pisarze wobec polskiego kodu kulturowego
}

Fundamentem łączącym danego pisarza $\mathrm{z}$ kulturą narodową jest przede wszystkim język właściwy jego dziełom. To on jest istotnym argumentem, także wówczas, gdy za bliskiego sobie, za własnego, uznaje twórcę kilka społeczeństw i literaturoznawcy je reprezentujący prowadzą merytoryczny spór. Tak argumentujemy, dyskutując choćby z braćmi Litwinami - Adam Mickiewicz napisał wprawdzie: „Litwo! Ojczyzno moja!”- - ale napisał po polsku.

Ów fundament, aczkolwiek niezbędny, stanowi jednak tylko punkt wyjścia dyskusji i rozważań. Następnymi nieodzownymi składnikami więzi z narodową kulturą są formułowane expressis verbis deklaracje przynależności znajdowane w dziełach literackich, a także w innych tekstach piśmiennych poety czy prozaika, listach, notatkach itd., stanowiące odzwierciedlenie świadomości narodowej piszącego. Twórca tak czy inaczej mówi: „Jestem jednym z Was, Wasza tożsamość jest moją tożsamością". Tak objawia światu, kim się czuje jako człowiek i za przedstawiciela jakiej kultury się uważa i uznaje. W ten sposób wskazuje społeczeństwo, do którego kieruje swoje utwory, definiuje grono oczekiwanych przez siebie odbiorców.

Opisany stan świadomości pisarza występuje w wielu odmianach. Twórca może afirmować kulturę narodową, uznając się bądź za wieszcza, bądź za zwykłego przedstawiciela bliskiego swemu sercu społeczeństwa. Najbardziej jednak wartościową formą takiej postawy artysty jest taka jej postać, gdy w jego dziełach ujawniają się narodowe „archetypy”, a więc gdy twórca zna nie tylko świadomość swego społeczeństwa, ale też zbiorową podświadomość (C.G. Jung). Pisarz odgrywa wówczas rolę nauczyciela swojego narodu, uświadamiając mu ważne komponenty zbiorowej tożsamości. Artysta przyczynia się w ten sposób do budowania i rozwoju świadomości narodowej, a czytelnicy przeglądając się w jego utworach, widzą samych siebie, widzą, jacy są naprawdę, co w ich wewnętrznej konstrukcji jest własne, a co jest obce.

Zdarzają się także pisarze, których afirmująca postawa wobec kultury narodowej łączy się z jednoznacznym nazywaniem narodowych przywar. Owe krytyczne uwagi formułowane są jednak w taki sposób, że odbiorcy uznają autora wypominającego im wady za dobrego koryfeusza z troską przyglądającego się tym, którzy powinni za nim podążać. Pisarz taki jawi się jako patriota-reformator, 
nie krytykuje bowiem z pozycji zewnętrznej, lecz wewnętrznej, a przy tym cechy wypominane tak naprawdę kocha i uznaje za swoje.

Mniej ścisły związek twórcy z narodem objawia się przez postawę patrioty zdystansowanego, na przykład przerażonego, który znajduje w świadomości społecznej cechy niepokojące, a nawet groźne dla jego dalszego bytu. Jest to stanowisko ambiwalentne, łączące afirmację z negacją. Ważne dla opisywanej postawy artysty jest jednak to, że zarówno miłość, jak i dezaprobata wyrażane są z pozycji wewnętrznej. Artysta daje wyraz, chcąc nie chcąc, że cechy tożsamości zarówno akceptowane, jak i krytykowane, należą do społeczeństwa, które jest jego społeczeństwem.

Inna postawa właściwa jest skrajnej opcji typowej nadal dla pozycji wewnętrznej. Pisarz dysponuje rozbudowaną świadomością narodową, ale nie akceptuje kultury będącej jego własną kulturą. Znamienne jest to dla artysty-wiecznego malkontenta. Pisarz mówi: „Moi ziomkowie mi się nie podobają, śmieszą mnie bądź irytują elementy naszego kodu kulturowego", ale do końca jego twórczości krytykowany kształt kultury pozostaje dla niego ważny. Postulowany proces separacji nie następuje.

Z kolei pisarz wyalienowany wobec kultury właściwej językowi, którym się posługuje, zdaje się mówić: „Nawet jeśli jestem pośród Was, to nie jestem z Wami. Jestem pośród Was samotny". Dla postawy takiej charakterystyczne jest przenikanie się pozycji wewnętrznej i zewnętrznej.

Stanowisko wewnętrzne zanika natomiast zupełnie, gdy pisarz zdecydowanie określa siebie jako obcego wobec kodu kulturowego narodu posługującego się językiem, w którym sam tworzy.

Jedną ze skrajnych postaw pozycji zewnętrznej jest faktyczna obojętność pisarza wobec kwestii tożsamości narodowej. Elementy właściwe wspólnocie przenikają do jego dzieł jakby bez udziału woli pisarza. Należy on jako artysta do kultury danego narodu niejako bezwiednie.

Wreszcie zdarza się, że twórca szczególnie akcentując swoją obecność, wybiera postawę walki z tym, co zna i rozpoznaje, ale nie uważa tego, jako spoglądający z pozycji zewnętrznej, za jakąkolwiek wartość. O przedstawicielach narodu, w którego języku się wypowiada, nie tylko mówi „oni”, lecz wypowiada się o tychże z pogardą i wyższością.

Każda $\mathrm{z}$ naszkicowanych tu postaw możliwa jest, rzecz jasna, w wielu indywidualnych odmianach związanych z różnymi historycznymi uwarunkowaniami, a także pokoleniowymi i osobistymi aspektami życia pisarza.

Niniejsze rozważania, skupione na postawie pisarzy wobec tego, co w kulturze narodowej istotne dla polskiej tożsamości, pragniemy wpisać w rocznicę stulecia odzyskania przez Polskę niepodległości jako polonistyczny, literaturoznawczy wkład w jej uroczyste obchody.

Mirostaw Olędzki 